\title{
Factores asociados a la supresión virológica sostenida en pacientes con VIH/sida con tratamiento antirretroviral, a través del Programa TARGA del Ministerio de Salud. 2004-2009
}

\author{
Zila Caballero, Nora Reyes, Javier Vargas, Paolo Wong, Jorge Alarcón, Giancarlo Salyrosas
}

Instituto de Medicina Tropical Daniel A. Carrión, Facultad de Medicina, UNMSM

\begin{abstract}
Objetivos: Medición del indicador de supresión virológica sostenida como respuesta exitosa a los 12 meses, en pacientes que iniciaron tratamiento gratuito durante el primer año del programa TARGA (2004).

Diseño: Observacional, descriptivo, longitudinal retrospectivo. Se tomó como universo a todos los pacientes adultos con $\mathrm{VIH} /$ sida que ingresaron al Programa TARGA durante el primer año y están registrados en bases de datos del MINSA. Institución: Instituto de Medicina Tropical Daniel A. Carrión, Facultad de Medicina, UNMSM.

Participantes: Pacientes con VIH/sida en TARGA de Hospitales públicos y ONGs.

Intervenciones: Se evaluó los resultados del dosaje plasmático de carga viral del VIH por método PCR. Se consideró como valor umbral máximo 1000 copias virales/mL para definir presencia de supresión viral. Se hizo una medición al inicio del tratamiento y luego mediciones cada 6 meses.

Principales medidas de resultados: Probabilidad de carga viral $<1000$ copias $/ \mathrm{mL}$ a los 6 y 12 meses de tratamiento. Resultados: Se demostró que, en esta cohorte, la probabilidad de alcanzar carga viral $<1000 \mathrm{copias} / \mathrm{mL}$ fue 0,16 (16\%) a los 6 meses de tratamiento. Y esta probabilidad se incrementó a 0,53 (53\%) a los 12 meses.

Conclusiones: El indicador evaluado demuestra un nivel medio-bajo de supresión virológica sostenida para este grupo de pacientes en el periodo señalado.
\end{abstract}

Palabras clave: VIH/sida, supresión viral sostenida.

\section{Relación del polimorfismo -866 en el gen de la proteína desaclopadora 2 (UCP2), con la obesidad infantil y factores de riesgo cardiovascular}

\author{
Jaime Pajuelo, Oscar Acosta, Doris Huerta, Torres Lizardo \\ Instituto de Investigaciones Clínicas y Centro de Investigación de Bioquimica y Nutrición, Facultad de Medicina, UNMSM.
}

Objetivos: Establecer relación entre el polimorfismo -866 G/A en el gen UCP2, estado nutricional y factores de riesgo cardiovascular en niñas.

Diseño: Descriptivo, relacional tipo casos-control.

Institución: Instituto de Investigaciones Clínicas y Centro de Investigación de Bioquímica y Nutrición, Facultad de Medicina, UNMSM.

Participantes: Niñas.

Intervenciones: En 100 niñas (50 con IMC normal 15 a 85, y 50 con IMC > 85), con promedio de edad 14 años, se hizo dosaje de glucosa, insulina y determinación del perfil coronario. Se extrajo el ADN genómico de las participantes, con análisis del polimorfismo -866 G/A en el gen UCP2 mediante técnica PCR/RFLP, con primers específicos y digestión con enzima de restricción Mlul; detección de los fragmentos por electroforesis geles de agarosa al $2 \%$ y tinción con bromuro de etidio.

Resultados: La distribución de los genotipos UCP2 en ambos grupos siguió la hipótesis del equilibrio de Hardy-Weinberg. No existieron diferencias significativas ( $p=0,80$, prueba $X_{2}$ ) cuando se comparó las frecuencias de los genotipos y alelos en los grupos sobrepeso-obesidad y normales. Igual tendencia se observó cuando, además, se consideró los niveles de glucosa, insulina, HOMA-I y perfil coronario.

Conclusiones: No existió relación entre el polimorfismo -866 en el gen UCP2 y el estado nutricional y factores de riesgo cardiovascular, en esta muestra infantil estudiada.

Palabras clave: Obesidad, riesgo cardiovascular, proteína desaclopadora, gen. 